\title{
Analisis Kinerja Pengrajin Perempuan di Batik Blimbing Malang
}

\author{
Asinta, Dyah P.M. Nurul Hidayati*, Endang Prahastuti \\ Universitas Negeri Malang, Jl. Semarang No. 5 Malang, Jawa Timur, Indonesia \\ *Penulis korespondensi, Surel: nurul.hidayati.ft@um.ac.id
}

Paper received: 07-03-2021; revised: 10-03-2021; accepted: 23-03-2021

\begin{abstract}
This study aims to analyze the performance of female artisan in work quantity indicators, work quality, and work effectiveness in accordance with the terms and conditions in Batik Blimbing. The data collected in this study is used as a reference for the performance of the female artisan so that when the results are good, batik entrepreneurs are expected to prioritize female artisans in carrying out their business. This type of research is descriptive qualitative with techniques for collecting data on interviews, observation and documentation. Check the validity of source triangulation data: Leader of Batik Blimbing, Manager of Management, Female Craftsmen. The female craftsmen have work performance with work quantity indicators, work quality and work effectiveness that can fulfill the requirements of the Blimbing Batik even though when the woman works women have a double duty. But because of the work system that makes craftsmen comfortable at work and also because of motivation support from within the family to help, the opportunity and workers who can do without special knowledge with education, make female craftsmen choose to become craftsmen because of the female character known with patience and painstakingness and the support of Blimbing Batik itself which prefers female craftsmen because it is known as a patient, painstaking and easier to teach character in batik making that requires high concentration. Based on the result of the study, it is suggested that batik entrepreneurs are expected to implement a work system that makes artisan have a longer working period so that the artisans' turnover is not too frequent and can work longer so the performance of female artisan can be increased. And the artisan can get a wider knowledge about batik, so that in the production process the female artisan can provide input and become more active in the production process, so that it is not monotonous to just follow the manager's instructions.
\end{abstract}

Keywords: craftswoman; performance; Batik Blimbing

\begin{abstract}
Abstrak
Penelitian ini menganalisis kinerja pengrajin perempuan dalam indikator kuantitas kerja, kualitas kerja dan efektivitas kerja sesuai dengan syarat dan ketentuan di Batik Blimbing, data yang dikumpulkan dalam peneltian ini digunakan untuk referensi kinerja pengrajin perempuan agar ketika hasil yang didapatkan baik, diharapkan para pengusaha batik lebih memperioritaskan pengrajin perempuan dalam menjalankan usahanya untuk mempercayai sebagai pengrajin yang bersangkutan. Jenis penelitian ini deskriptif kualitatif dengan teknik pengumpulan data wawancara, observasi dan dokumentasi. Pengecekan keabsahan data triangulasi sumber: Pemimpin Batik Blimbing, Manager Pengelola, Pengrajin perempuan. Para pengrajin perempuan memiliki kinerja kerja dengan indikator kuantitas kerja, kualitas kerja dan efektivitas kerja yang dapat memenuhi syarat ketentuan di Batik Blimbing meskipun ketika perempuan itu bekerja perempuan memiliki tugas ganda. Tetapi karena sistem pekerjaan yang membuat para pengrajin nyaman dalam bekerja dan juga karena adanya dukungan motivasi dari dalam keluarga untuk membantu, adanya kesempatan dan pekerja yang bisa lakukan tanpa adanya pengetahuan khusus dengan jengjang pendidikan, membuat para pengrajin perempuan memilih untuk menjadi pengrajin karena karakter perempuan yang dikenal dengan sabar dan telaten dan adanya dukungan di Batik Blimbing sendiri yang lebih memilih pengrajin perempuan karena dikenal dengan karakter yang sabar, telaten dan lebih mudah untuk diajarkan dalam hal membatik yang membutuhkan konsentrasi yang tinggi. Berdasarkan hasil penelitian disarankan mewujudkan peningkatan kinerja pengrajin perempuan di Batik Blimbing dengan Adanya kontrak kerja yang membuat para pengrajin perempuan dapat bekerja lebih lama agar kesalahan dalam proses membatik dapat diminimalisir dan pengrajin dapat
\end{abstract}


menjadi lebih terampil dalam membatik. Para pengrajin dapat pembelajaran yang lebih luas tentang batik, sehingga dalam proses produksi para pengrajin perempuan bisa memberikan masukan dan lebih aktif dalam proses produksi, sehingga tidak monoton hanya mengikuti instruksi dari manager pengelola.

Kata kunci: pengrajin perempuan; kinerja; Batik Blimbing

\section{Pendahuluan}

Peningkatan ekonomi dengan pengelolaan Industri di Kota Malang baik Industri kecil atau Industri besar menjadi salah satu jalan keluar dalam menaikan pendapat dan mengurangi pengangguran. Perkembangan usaha masih dikuasai oleh kaum pria sampai saat ini. Casson (2006) Hal ini dikarenakan secara historis kewirausahaan merupakan bidang kekuasaan bagi kaum pria. Menjadikan kalangan perempuan dalam bekerja masih menjadi kalangan minoritas dalam pengembangan usaha. Industri Tekstil merupakan industri padat karya yang membuat para perempuan lebih banyak bekerja di bidang ini. Melihat ada beberapa aspek pendorong yang membuat perempuan bekerja yaitu memberikan sumbangan pendapat berupa ide, menjadikan perempuan lebih dibutuhkan dalam perindustrian. Sebenarnya sudah sejak lama perempuan ikut ambil bagian dalam pembangunan ekonomi walaupun terbatas pada perannya dalam mengurus kegiatan rumah tangga, akan tetapi adanya perubahan sosial yang bergeser, sehingga peran perempuan tidak sepenuhnya memenuhi kebutuhan domestik saja, melainkan juga dituntut perannya dalam kehidupan kemasyarakatan dan ikut bekerja disamping suami untuk mencari nafkah dalam mensejahterakan keluarganya. Kinerja menurut Kamus Besar Bahasa Indonesia merupakan apa yang dicapai atau presentasi kerja yang telah dicapai. (Sofyan, 2013) menyatakan salah satu gambaran tentang pegawai atau karyawan yang diberi rasa tanggung jawab selama bekerja. Kinerja juga merupakan bandingan baik dan buruknya aktivitas melalui hasil-hasil yang dicapai sesuai dengan tujuan organisasi. Perempuan yang bekerja memiliki status menikah maka perempuan mempunyai banyak peran dalam kehidupannya tidak hanya untuk menambah ekonomi tetapi juga menjadi seorang ibu. Perempuan juga menghadapi tekanan dimana hal ini berhubungan erat dengan status sosial ekonomi budaya, peranan dalam keluarga, dan perannya sebagai pencari nafkah. Menurut Anshori (dalam Wulandari, 2002) peranan perempuan dapat dikelompokkan menjadi 3 yaitu peran sebagai istri, ibu, dan anggota masyarakat.

Peran sebagai istri dan ibu merupakan peran domestik sedangkan peran sebagai anggota masyarakat dikategorikan sebagai peran publik. Adapun peran domestik menuntut seorang perempuan untuk melaksanakan tugas kodratinya dan mengelola rumah tangganya tanpa mendapatkan gaji, sedangkan peran publik berkaitan dengan pekerjaan dan karier yang menghasilkan gaji. Dengan keadaan yang sangat padat dan melelahkan sedangkan pekerjaan yang dilakukan harus menghasilkan produk yang baik padahal batik memerlukan waktu yang tidak sedikit dan memerlukan tenaga yang baik dan pemikiran yang baik agar dapat menghasilkan produk yang berkualitas.

Batik Blimbing Malang merupakan salah satu pengusaha batik yang ada di Kota Malang dengan membuka tempat pelatihan dan kegiatan untuk masyarakat umum guna memperkenalkan dan mengajarkan membatik kepada setiap masyarakat yang ingin belajar dan lebih mengenal batik khas Kota Malang. Batik Blimbing Malang mengambil pengrajin yang biasanya bermula dari mengikuti kegiatan di Batik Blimbing Malang yang rata-rata dipenuhi 
dengan pengrajin perempuan, Batik Blimbing mempunyai 7 pengrajin perempuan dengan kisaran usia 18-45 tahun dengan pengalaman pengrajin dari yang terlama 8 tahun sampai yang baru 1 bulan tetapi semua pekerjaan di sama ratakan dalam diberikan tanggung jawab membatik dengan mengukur kinerja sebagai gaji yang di akan dapatkan. Proses produksi di utamakan di tempat usaha yang telah disediakan karena Batik Blimbing Malang juga mengutamakan kenyamanan untuk pengrajinya dalam membatik dan agar bisa di kontrol dalam proses pembuatan menjadikan produk yang dihasilkan sesuai dengan yang di targetkan.

\section{Metode}

Penelitian ini jenis penelitian deskriptif kualitatif. Lokasi penelitian dilakukan di Batik Blimbing Malang alamat Jl.Candi Jago No 06. Teknik pengambilan data menggunakan metode wawancara, observasi dan dokumentasi. Menggunakan dua sumber data primer dari hasil wawancara, observasi dan dokumentasi dan data sekunder mengenai dokumen terkait. Keabsahan data penelitian menggunakan triangulasi sumber yaitu pemimpin, manager pengelola dan pengrajin perempuan, dengan sampel 6 pengrajin perempuan. Data penelitian ini berupa (1) kuantitas kerja pengrajin perempuan (2) kualitas kerja pengrajin perempuan (3) efektivitas kerja pengrajin perempuan. Analisis data yang dilakukan hasil observasi, wawancara, catatan lapangan dan dokumentasi dengan mengelompokkan kedalam kategori menjabarkan ke unit-unit, melakukan analisa, menyusun kedalam draf dan membuat kesimpulan.

\section{Hasil dan Pembahasan}

Industri kreatif salah satunya usaha Batik yang proses produksi membutuhkan kesabaran, ketelatenan, keterampilan dan keuletan, yang mana dulu membatik itu merupakan pekerjaan eksklusif para perempuan jawa. Penelitian ini menemukan beberapa temuan penelitian dalam kinerja pengrajin perempuan dalam indikator kuantitas kerja, kualitas kerja, dan efektivitas kerja di Batik Blimbing Malang.

\subsection{Kuantitas Kinerja Pengrajin Perempuan}

Kuantitas merupakan jumlah yang harus diselesaikan, diketahui bahwa jumlah produksi di Batik Blimbing tidak mempunyai jumlah yang tetap padahal menurut Robbins (2018) menjelaskan kuantitas adalah segala bentuk ukuran yang terkait dengan jumlah hasil kerja dan dinyatakan dalam ukuran angka. Sehingga bisa dibuat kisaran 10-20 produk. Ditambah dengan jumlah produk yang bersifat kumulatif jika adanya permintaan ataupun pemesanan. Penjelasan Zulkifli (2015) jumlah hasil kerja yang dilakukan dalam satu periode yang ditentukan. Pengukuran dalam jumlah produksi di Industri kreatif bisa dibilang bersifat tidak tetap. Berdasarkan wawancara dari manajer pengelola dan pemimpin Batik Blimbing bahwa dalam satu periode dihitung dalam satu bulan dengan kisaran 10-20 batik yang diproduksi oleh para pengrajin perempuan dengan jumlah yang tidak tetap dan dapat berubah sesuai dengan kebutuhan pemesanan pelanggan.

Di Batik Blimbing sendiri pekerjaan yang dilakukan setiap hari meskipun tidak memiliki patokan yang tetap para pengrajin perempuan tetap melakukan pekerjaannya setiap hari, sehingga para pengrajin tetap menghasilkan pekerjaan setiap hari dengan arahan yang ditentukan, ini sejalan dengan Fauzi (2014) kemampuan pegawai dalam menyelesaikan sejumlah hasil pekerjaan setiap harinya. Para pengrajin perempuan melakukan pekerjaan setiap harinya memberikan hasil kerja dengan memenuhi produk yang akan dipasarkan. Para 
pengrajin perempuan yang mempunyai karakter lebih banyak berbicara sehingga ketika pekerjaan dilakukan dengan bersama-sama dapat dilakukan dengan nyaman dan cepat. Meskipun memiliki tugas yang banyak ketika adanya pemesanan.

Menurut Arianty (2014) kuantitas kerja dapat diukur melalui penambahan nilai dan barang dari hasil sebelumnya. Penambahan barang dan nilai dapat diartikan bahwa meningkatnya jumlah permintaan membuktikan kuantitas kerja baik dalam mencapai target yang ditentukan, peningkatan jumlah pemesanan dan permintaan di Batik Blimbing sudah tergolong sangat luas dan banyak dengan hasil observasi yang didapat, bahwa Batik Blimbing pernah menerima pemesanan untuk jumlah di atas 100 pcs kain batik. Para pengrajin perempuan telah melakukan pekerjaanya sesuai dengan ketentuan di Batik Blimbing karena para pengrajin perempuan dapat menyelesaikan target yang berikan meskipun dalam keadaan mendadak dengan bertambahnya jumlah produksi yang semakin meningkat, jumlah pengrajin perempuan yang sedikit berjumlah 6 orang dengan sistem pekerjaan yang dilakukan secara bersama-sama.

\subsection{Kualitas Kinerja Pengrajin Perempuan}

Kualitas kinerja mempunyai beberapa sub indikator mengenai tingkat kesalahan, pengetahuan, keterampilan dan abilities.

\subsubsection{Tingkat kesalahan}

Temuan hasil wawancara narasumber untuk mengetahui tingkat kesalahan di Batik Belimbing yaitu kesalahan yang terjadi di bagian mencanting dan mewarnai merupakan pekerjaan pokok yang tingkat kesulitan lebih tinggi dibandingkan dengan tingkat pekerjaan yang lain, kesalahan yang paling banyak ditemukan yaitu pada saat mencanting dan mewarnai. Sedangkan kualitas pekerjaan menurut Fauzi (2014) kemampuan pegawai menunjukkan kualitas hasil kerja yang ditinjau dari segi ketelitian dan kerapian. Dalam usaha industri yang tidak dipungkiri lagi bahwa seringnya terjadi pergantian pekerja yang menyebabkan tingkat kesalahan dalam produksi rentan terjadi, di Batik Blimbing para pengrajin perempuan yang paling lama bekerja sudah 7 tahun dan yang paling baru 3 bulan dan jumlah pengrajin 7 orang, pengambilan data diambil pada bulan agustus 2018, dan pada bulan Maret 2019 jumlah pengrajin sudah berkurang menjadi 6 Pengrajin, sehingga dengan seringnya jumlah pengrajin yang sering berganti membuat para pengrajin belum menjadi profesional dalam bidangnya, dan juga para pengrajin perempuan yang bekerja mempunyai peran ganda berupa istri dan mencari nafkah sehingga energi dalam bekerja dapat berkurang tanpa disadari, dan juga faktor internal seperti menikah dan melahirkan yang memutuskan untuk menghentikan pekerjaan. Untuk menjaga kualitas produk dan kualitas pekerja harus berjalan dengan seimbang, sehingga kesalahan yang dialami oleh para pengrajin masih tergolong dalam batas wajar sesuai dengan keinginan Batik Blimbing didukung oleh menerapkan batik dengan menggunakan canting elektrik dan pengawasan yang rutin oleh manajer produksi sehingga para pengrajin perempuan yang memiliki rasa takut lebih banyak menjadikan para pengrajin perempuan bekerja lebih teliti dan giat agar terhindar dari kesalahan.

\subsubsection{Pengetahuan}

Pengetahuan adalah informasi yang dimiliki seseorang dalam bidang tertentu, temuan data penelitian bahwa para pengrajin perempuan di Batik Blimbing pada saat awal bekerja 
kebanyakan tidak tau apa itu batik dan tidak tau bagaimana caranya membatik, padahal menurut suhartini (2015) pengetahuan mencerminkan kemampuan kognitif seseorang dalam menjalani tugas atau pekerjaannya. Padahal kebanyakan dari para pengrajin perempuan hanya lulusan setingkat SMP sehingga membuat kurangnya pengetahuan akan membatik. oleh karena itu untuk mengatasi masalah tersebut para pengrajin perempuan di Batik Blimbing sebelum bekerja akan diberi pengetahuan tentang proses membatik sehingga setelah mengerti dan memahami cara proses produksi baru lah dilepas untuk bekerja secara nyata, sehingga para pengrajin sebenarnya tanpa disadari sudah memiliki pengetahuan secara tidak langsung dari saat pelatihan untuk menjadi pengrajin di Batik Blimbing.

\subsubsection{Keterampilan}

Temuan penelitian menemukan bahwa keterampilan mempengaruhi hasil batik dari lama nya dia bekerja sehingga pernyataan ini sejalan dengan Suhartini (2015) menyebutkan keterampilan merupakan sebagai kapasitas yang dibutuhkan untuk melaksanakan suatu rangkaian tugas yang berkembang dari hasil pelatihan dan pengalaman. Sedangkan pengalaman seseorang dalam bekerja dapat memperdalam kemampuannya saat bekerja. Para pengrajin perempuan yang terampil tidak lepas dari lamanya dia bekerja, tetapi dikarenakan perempuan yang memiliki banyak halangan sehingga seringnya pergantian pengrajin yang membuat keterampilan perempuan dalam hal membatik sangat kurang padahal para perempuan yang sudah terkenal dengan karakternya yang sabar dan telaten membuat para pengrajin perempuan akan memiliki tingkat keterampilan yang lebih cepat yang akan memiliki kualitas keterampilan yang diinginkan di industri Batik, dan para perempuan juga memiliki selera yang lebih tinggi dibandingkan pria dikarenakan pria yang cenderung lebih mengikuti dan menerima, sehingga jika di tuangkan pada saat bekerja di industri batik contohnya pada saat mendesain batik dan mewarnai perempuan yang memiliki keterampilan yang tinggi akan cenderung memberikan saran dan pendapatnya, sehingga ketika para pengrajin perempuan ini memiliki keterampilan yang tinggi akan sangat membantu dalam proses produksi.

\subsubsection{Abilities}

Abilities atau bisa disebut dengan kemampuan yaitu menurut Suhartini (2015) kemampuan pegawai dalam melaksanakan tugasnya dalam perwujudan dari pengetahuan dan keterampilan yang dimiliki, dalam paparan data yang telah ditemukan abilities pengrajin perempuan di batik Blimbing Abilities hanya dituntut dalam kemampuan produksi tetapi juga memiliki kemampuan dalam mengatasi kondisi ditempat kerja dan melayani konsumen secara langsung.

Indria (2016) menjelaskan bahwa perempuan memiliki bakat alami dalam mengerjakan pekerjaan yang rumit serta memiliki kecekatan dan ketepatan yang tinggi. sehingga Para pengrajin perempuan memang tidak memiliki kesusahan dalam abilities pada saat dituntut untuk kemampuan yang tidak hanya di bidang produksi, tetapi juga mengatasi kondisi ditempat kerja dan melayani konsumen, karena banyaknya aktivitas yang dilakukan di rumah ataupun tempat kerja menjadi perempuan terbiasa dengan segala aktivitas yang dilakukan sehingga dapat dilakukan dengan apa yang diperintahkan. Dan juga pekerjaan membatik tidak membebani pekerjaan yang akan dibawa pulang maka para pengrajin perempuan akan melaksanakan tugasnya sebagai pengrajin ditempat kerja dan melepaskan beban ketika bekerja sesudah sampai dirumah. Dikarenakan adanya tuntutan dalam bekerja dan 
komunikasi yang baik antar pengrajin perempuan, pengelola dan pemilik sehingga abilities pengrajin perempuan bisa dikatakan sesuai dengan ketentuan dan syarat di Batik Blimbing.

\subsection{Efektivitas Kinerja Pengrajin Perempuan}

Temuan efektivitas kinerja ada beberapa sub indikator mengenai efektivitas kerja berupa waktu pekerjaan dan mengatasi kendala. Berdasarkan paparan data yang telah ditemukan bahwa waktu pekerjaan para pengrajin perempuan melakukan proses produksi secara terus-menerus dan terarah meskipun waktu dalam proses produksi dilakukan secara fleksibel. Waktu pekerjaan yang diberikan untuk para pengrajin perempuan dilakukan secara fleksibel tetapi ketika adanya pemesanan baru dilakukan tahapan waktu untuk mencapai target yang ditentukan. Sehingga para pengrajin perempuan dapat menyelesaikan target yang diberikan pada saat pemesanan dan tetap melakukan pekerjaan secara terus-menerus meskipun tidak adanya pemesanan sampai batas waktu yang kerja yang ditetapkan.

Mengatasi kendala dalam setiap proses produksi karena adanya komunikasi yang baik antar pengrajin, pengelola dan pemimpin produksi, dalam menjalankan efektivitas yang baik seperti yang diungkapkan oleh Rizal (2011) pemimpin merupakan pusat informasi yang dibutuhkan untuk memudahkan pekerja dalam melaksanakan tugas-tugasnya dalam mencapai tujuan organisasi secara efektif dan juga dari hasil observasi para pengrajin perempuan jarang menghadapi kendala dalam proses produksi dikarenakan di tempat produksi yang sudah baik dari segi alat dan bahan yang sudah dikelola dengan maksimal, mengikuti perkembangan teknologi, adanya komunikasi yang baik antar dua arah, sarana dan prasarana yang memadai.

\section{Simpulan}

\subsection{Kesimpulan}

Para pengrajin perempuan memiliki kinerja kerja dengan indikator kuantitas kerja, kualitas kerja dan efektivitas kerja yang dapat memenuhi syarat ketentuan di Batik Blimbing meskipun ketika perempuan itu bekerja perempuan memiliki tugas ganda yang dapat menyebabkan keterbatasan kerja pada diri sendiri yaitu keterbatasan tenaga yang menyebabkan lelah fisik dan mental, serta adanya kejenuhan dalam melakukan semua perannya sehingga membuat mereka malas dalam menjalankan semua peran baik ketika dirumah maupun bekerja. Tetapi karena adanya Fasilitas di Batik Blimbing dengan sistem pekerjaan yang membuat para pengrajin nyaman dalam bekerja dan juga karena adanya dukungan motivasi dari dalam keluarga sebagai pencari nafkah tambahan untuk membantu perekonomian keluarga maka para pengrajin dapat bekerja sesuai dengan tujuan yang ditetapkan agar mendapatkan gaji padahal ketika para pengrajin perempuan itu bekerja tidak menjamin untuk kesejahteraan perempuan karena mengingat faktor gaji yang diterima masih cukup rendah, sehingga adanya beberapa kesempatan dan pekerja yang bisa dilakukan tanpa adanya pengetahuan khusus dengan jenjang pendidikan, membuat para pengrajin perempuan memilih untuk menjadi pengrajin karena karakter perempuan yang dikenal dengan sabar dan telaten menjadikan para perempuan memilih untuk menjadi pengrajin yang dianggap cukup sebagai syarat bekerja dan juga adanya dukungan di Batik Blimbing sendiri yang lebih memilih pengrajin perempuan karena dikenal dengan karakter yang sabar, telaten dan lebih mudah untuk diajarkan dalam hal membatik yang membutuhkan konsentrasi yang tinggi. 


\subsection{Saran}

Adapun saran-saran penulis berdasarkan kesimpulan yang didapat untuk bermanfaatnya penulisan ini, maka penulis merekomendasikan beberapa hal dalam mewujudkan peningkatan kinerja pengrajin perempuan di Batik Blimbing: Dikarenakan seringnya pergantian pengrajin perempuan disebabkan beberapa faktor seperti menikah dan mempunyai anak, membuat pengrajin perempuan lebih cenderung tidak mempunyai jangka waktu yang lama dalam bekerja sehingga membuat keahlian dalam membatik berkurang, maka diharapkan para pengusaha batik menerapkan sistem kerja yang membuat para pengrajin mempunyai masa kerja yang lebih lama sehingga pergantian pengrajin tidak terlalu sering dan dapat bekerja lebih lama agar kinerja pengrajin perempuan dapat lebih meningkat.

\section{Daftar Rujukan}

Abdullah, M. R. (2014). Manajemen dan evaluasi kinerja karyawan. Yogyakarta: Aswaja Perssindo.

Arianty, N. (2015). Pengaruh budaya organisasi terhadap kinerja pegawai. Jurnal Ilmiah Manajemen dan Bisnis, 14(2).

Bernaldin, R. (2003). Human Resources Management: an Experimental Approach, International Edition. McGraw Hill Inc. Singapore.

Casson, M., Yeung, B., \& Basu, A. (Eds.). (2008). The Oxford handbook of entrepreneurship. New York: Oxford University Press Inc.

Hasibuan, M. (2006). Manajeman Sumber Daya Manusia Edisi Revisi. Jakarta: PT. Bumi Aksara.

PK, A. I. M. (2009). Analisis kinerja pegawai bagian humas berdasarkan tugas pokok dan fungsi public relations.

Mahesa, D., \& Djastuti, I. (2010). Analisis Pengaruh Motivasi dan Kepuasan Kerja terhadap Kinerja Karyawan dengan Lama Kerja sebagai Variabel Moderating (Studi pada PT. Coca Cola Amatil Indonesia (Central Java) (Doctoral dissertation, UNIVERSITAS DIPONEGORO).

Sofyan, D. K. (2013). Pengaruh Lingkungan Kerja Terhadap Kinerja Kerja Pegawai BAPPEDA. Industrial Engineering Journal, 2(1).

Megantoro, D. (2015). Pengaruh Keterampilan, Pengalaman, Kemampuan Sumber Daya Manusia terhadap Usaha Kecil Menengah (Studi Kasus di Panjangrejo, Srihardono, Pundong, Bantul Yogyakarta). Universitas PGRI Yogyakarta.

Moeheriono, M. (2012). Pengukuran kinerja berbasis kompetensi. Jakarta. PT.RajaGrafindo Persada.

Moeheriono, M. (2012). Pengukuran Kinerja Berbasis Kompetensi. Edisi Revisi. Jakarta: PT Raja Grafindo Persada.

Primadanti, A., \& Rahardja, E. (2017). Pengaruh Pengetahuan, Keterampilan, dan Kemampuan Karyawan Terhadap Kinerja Karyawan (Studi pada Karyawan PT. Mirambi Energi, Semarang) (Doctoral dissertation, Fakultas Ekonomika dan Bisnis). 